\title{
Inflammasomes: caspase-1-activating platforms with critical roles in host defense
}

\author{
Lieselotte Vande Walle ${ }^{1,2}$ and Mohamed Lamkanfi ${ }^{1,2 *}$ \\ Department of Biochemistry, Ghent University, Ghent, Belgium \\ Department of Medical Protein Research, Vlaams Instituut voor Biotechnologie, Ghent, Belgium
}

Edited by:

Amal Amer, The Ohio State University, USA

\section{Reviewed by:}

Amal Amer, The Ohio State University, USA

Luiz Bermudez, Oregon State

University, USA

Suzana P. Salcedo, Centre

$d^{\prime}$ Immunologie de Marseille-Luminy,

France

\section{${ }^{*}$ Correspondence:}

Mohamed Lamkanfi, Department of

Biochemistry, Ghent University, Albert

Baertsoenkaai 3, B-9000 Ghent,

Belgium.

e-mail:mohamed.lamkanfi@vib-ugent.be
Activation of the inflammatory cysteine protease caspase-1 in inflammasome complexes plays a critical role in the host response to microbial infections. Inflammasome activation induces inflammation through secretion of the pro-inflammatory cytokines interleukin (IL)-1 $\beta$ and IL-18 and through extracellular release of the alarmin high mobility group box 1. Moreover, caspase-1 activation by inflammasomes counters bacterial replication and induces pyroptosis, a specialized cell death program that removes infected immune cells as part of the host defense system. It is thus not surprising that bacterial and viral pathogens evolved virulence factors targeting inflammasome activation and activity. Here, we provide an overview of the distinct inflammasome complexes that are activated in a pathogen-specific manner and discuss the diverse strategies employed by viruses and bacteria to modulate inflammasome function.

Keywords: caspase-1, inflammasome, NOD-like receptors, pathogen, interleukin, pyroptosis, infection

\section{CASPASE-1: AN INFLAMMATORY CYSTEINE PROTEASE}

Caspases are evolutionary conserved cysteine proteases that cleave their substrates behind aspartate residues (Lamkanfi et al., 2002). Caspase-mediated substrate proteolysis results in activation or inactivation of critical signaling cascades regulating programmed cell death, differentiation, and cell proliferation (Lamkanfi et al., 2006). Dysregulated activity of the founding father of mammalian caspases, interleukin (IL)-1 $\beta$-converting enzyme and later renamed caspase-1, has been linked to inflammatory bowel diseases (Villani et al., 2009; Allen et al., 2010; Dupaul-Chicoine et al., 2010; Zaki et al., 2010a,b), gouty arthritis (Martinon et al., 2006), type II diabetes (Larsen et al., 2007), and less common autoinflammatory disorders that are collectively referred to as cryopyrinopathies (Lamkanfi and Kanneganti, 2010).

Caspase-1 modulates inflammatory and host defense responses against microbial pathogens by processing the precursor forms of the pro-inflammatory cytokines IL-1 $\beta$ and IL-18 into their biologically active forms (Kuida et al., 1995; Li et al., 1995; Ghayur et al., 1997; Gu et al., 1997). Caspase-1-mediated maturation of IL- $1 \beta$ and IL-18 is critical for their secretion from activated monocytes and macrophages. These related cytokines mediate critical aspects of the local and systemic immune response to infection including the induction of fever, transmigration of leukocytes into sites of injury or infection, and activation and polarization of $\mathrm{T}$ helper $1\left(\mathrm{~T}_{\mathrm{H}} 1\right)$ and $\mathrm{T}_{\mathrm{H}} 2$ responses (Dinarello, 2009). In addition to secreting IL- $1 \beta$ and IL-18, caspase- 1 also mediates the release of the damage-associated molecular pattern (DAMP) high mobility group box 1 (HMGB1) from macrophages infected with the facultative intracellular pathogen Salmonella typhimurium (Lamkanfi et al., 2010). Moreover, caspase-1 was shown to activate the executioner caspase-7 (Lamkanfi et al., 2008; Akhter et al., 2009), to inactivate glycolysis enzymes (Shao et al., 2007), and to induce a specialized form of cell death known as "pyroptosis" in macrophages infected with the bacterial pathogens Shigella flexneri, S. typhimurium, Pseudomonas aeruginosa, Legionella pneumophila, Bacillus anthracis, Staphylococcus aureus, Listeria monocytogenes, and Francisella tularensis (Lamkanfi and Dixit, 2010). In addition to preventing pathogen replication in infected immune cells, pyroptosis may enhance host defense responses by presenting intracellular microbial antigens to cells of the immune system (Lamkanfi and Dixit, 2010; Miao et al., 2010).

\section{CASPASE-1 ACTIVATION BY INFLAMMASOMES}

Caspase- 1 is produced as an inactive zymogen that is recruited and activated by cytosolic multi-protein complexes known as inflammasomes (Lamkanfi and Dixit, 2009). These protein complexes are assembled in cells of myeloid and epithelial origin upon recognition of DAMPs and pathogen-associated molecular patterns in intracellular compartments, similar to the role of mammalian Toll-like receptors at the cell surface and within endosomes (Kawai and Akira, 2006). Inflammasomes contain members of the NODlike receptor (NLR) or the HIN-200 receptor family, namely the NLRs Nlp1b, Nlrp3, and Nlrc4, or the HIN-200 protein absent in melanoma (AIM2; Figure 1). These receptors are recruited into the inflammasome in a pathogen-specific manner (Lamkanfi and Dixit, 2009). Nlrp3 is required for caspase-1 activation in response to microbial products with diverse molecular structures such as LPS, peptidoglycan, and lipoteichoic acid, upon exposure to microbial toxins and ionophores such as nigericin, endogenous alarmins such as ATP, and in response to infection with bacterial and fungal pathogens such as S. aureus, Streptococcus pneumoniae, and Candida albicans, respectively (Kanneganti et al., 2006a,b; 


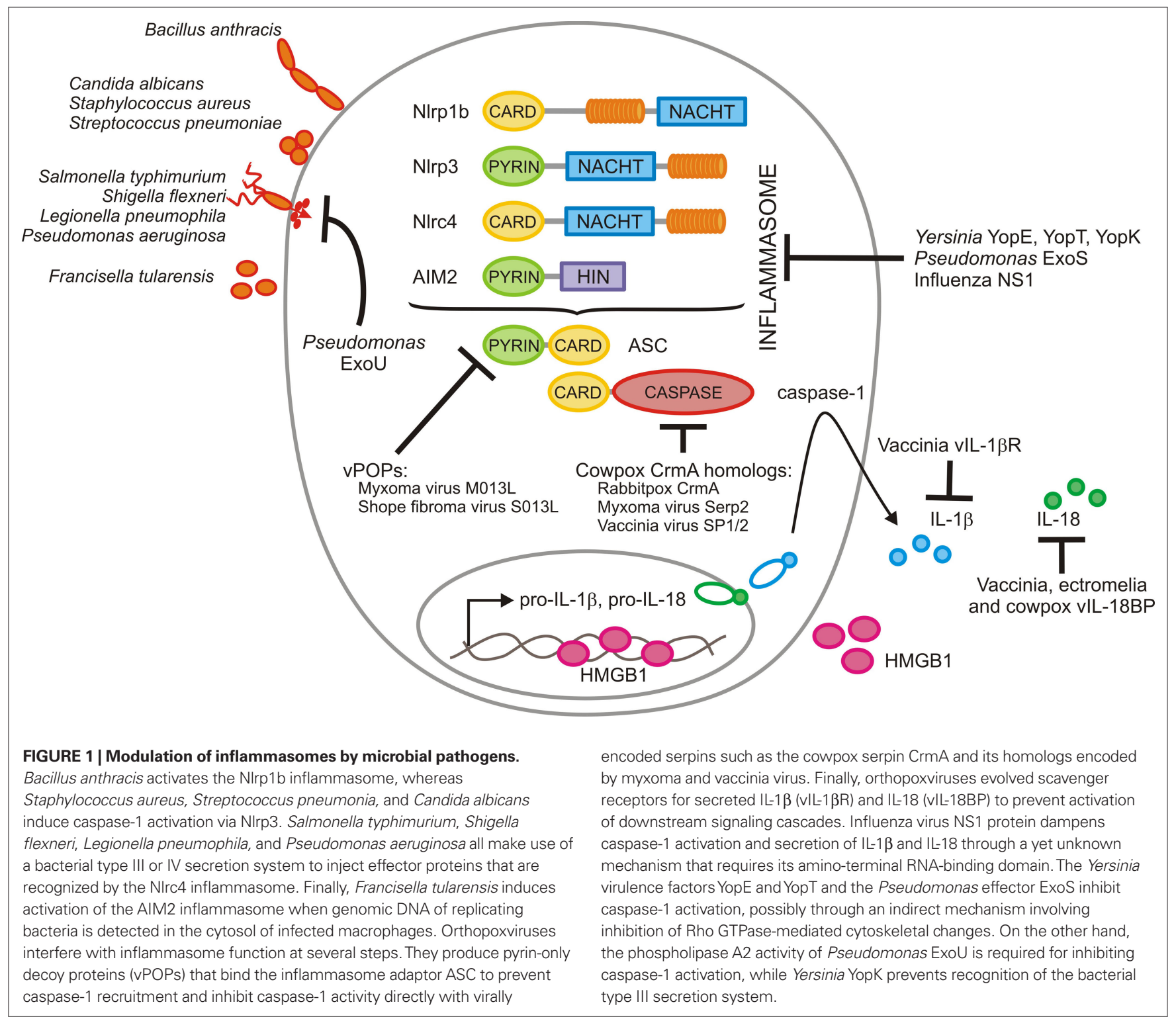

Mariathasan et al., 2006; Sutterwala et al., 2006; McNeela et al., 2010). In addition, the DAMPs monosodium urate and calcium pyrophosphate dehydrate crystals also activate the Nlrp3 inflammasome, suggesting a role for this inflammasome in the etiology of gouty arthritis and pseudogout (Martinon et al., 2006). By contrast, the Nlrc4 inflammasome is activated in macrophages infected with intracellular pathogens such as S. typhimurium, L. pneumophila, $P$. aeruginosa, and $S$. flexneri as illustrated by the observation that caspase-1 activation is largely abolished in Ipaf deficient macrophages infected with these intracellular pathogens (Mariathasan et al., 2004; Amer et al., 2006; Franchi et al., 2006, 2007; Miao et al., 2006, 2008; Lamkanfi et al., 2007a; Sutterwala et al., 2007; Suzuki et al., 2007). In contrast, B. anthracis Lethal Toxin (LT) triggers activation of the Nlrp1b inflammasome in mouse macrophages and mutations in the Nlrp1b gene were identified as the key susceptibility locus for Anthrax LT-induced macrophage death (Boyden and Dietrich, 2006). Finally, additional inflammasome complexes such as the recently identified AIM2 inflammasome, are responsible for

activation of caspase-1 in macrophages infected with F. tularensis, L. monocytogenes and in response to DNA viruses such as cytomegalovirus and vaccinia virus (Fernandes-Alnemri et al., 2010; Jones et al., 2010; Rathinam et al., 2010; Sauer et al., 2010).

\section{CASPASE-1 INHIBITION BY ORTHOPOXVIRUS-ENCODED SERPINS}

Given the central role inflammasomes play in modulating replication and dissemination of microbial pathogens, certain viruses and bacteria have evolved mechanisms to counter the induction of caspase- 1 activation and activity. One mechanism by which microbial pathogens interfere with inflammasome functions is by directly targeting the enzymatic activity of caspase-1. The cowpox virus protein Cytokine response modifier A (CrmA) and its homologs in orthopoxviruses such as vaccinia, ectromelia, and rabbitpox virus probably represent the best characterized examples of this class of inflammasome inhibitors (Dobbelstein and Shenk, 1996; Macen et al., 1996; Turner et al., 2000; Best, 2008). 
Although classified as serine protease inhibitors (serpins), these virus-encoded proteins function as pseudosubstrate inhibitors of caspase-1 (Ray et al., 1992; Komiyama et al., 1994; Best, 2008). They form covalent bonds with the active site cysteine after being processed by caspase-1, thus blocking its enzymatic activity. Indeed, CrmA inhibits caspase- 1 activity with a $K_{\mathrm{I}}$ of $0.01 \mathrm{nM}$, rendering it one of the most effective inhibitors known for this protease. Notably, CrmA shares 54\% amino acid identity with the human serpin PI-9 (Sprecher et al., 1995) and has two homologs in rodents (Sun et al., 1997). Although the reactive loop aspartate residue where caspase-mediated processing occurs in CrmA is mutated to glutamate in PI-9 (Annand et al., 1999), the latter serpin is capable of inhibiting caspases as illustrated by the observation that it prevents caspase-1-mediated processing of IL-1 $\beta$ and IL-18 in vascular smooth muscle cells (Young et al., 2000). Importantly, in addition to blocking caspase- 1 activation, CrmA and its homologs inhibit the protease activity of the apoptotic initiators caspases- 8 and -10 as well (Dobbelstein and Shenk, 1996; Macen et al., 1996; Turner et al., 2000; Best, 2008). Thus, poxviruses have devised a way to simultaneously interfere with inflammatory and apoptotic signaling cascades. Serpin-mediated caspase- 1 inhibition prevents secretion of IL-1 $\beta$ and IL-18 and delays the induction of effective host defense responses. Moreover, by preventing programmed cell death of infected host cells, poxviruses can replicate in intracellular niches and spread to adjacent cells before being recognized by cells of the host's immune system.

The critical role of CrmA and other serpins in poxvirus virulence is demonstrated by the observation that CrmA deficiency reduced the lesion size and numbers on the chorio-allantoic membrane of developing chick embryos (Ray et al., 1992; Palumbo et al., 1994). Moreover, deletion of CrmA attenuated virulence in intranasally and intracranially infected Balb/c and C57BL/6 mice (Thompson et al., 1993; Palumbo et al., 1994; MacNeill et al., 2009). Similarly, deletion of the CrmA homolog Serp2 in myxoma virus causes a dramatic reduction in viral titers in infected rabbits (Messud-Petit et al., 1998). By contrast, vaccinia virus mutants lacking the CrmA homologs SPI-1 and SPI-2 did not display changes in virulence in intranasally infected Balb/c mice (Kettle et al., 1995). This may be explained by the observation that vaccinia virus encodes a scavenger receptor called virus-encoded IL- $1 \beta$ receptor (vIL-1 $\beta R$ ) that neutralizes secreted IL-1 $\beta$ (Kettle et al., 1997). In addition, vaccinia, ectromelia, and cowpox viruses encode soluble IL-18-binding proteins (vIL-18BPs) that prevent activation of inflammatory pathways downstream of the IL-18 receptor (Smith et al., 2000). Thus, orthopoxviruses make use of serpins to inhibit caspase-1 activity and modulate signaling downstream of caspase- 1 through scavenger receptors to increase virulence.

\section{INHIBITION OF INFLAMMASOME ASSEMBLY BY ORTHOPOXVIRUS DECOY PROTEINS}

In addition to modulating inflammasome signaling at the level of caspase- 1 and its substrates, orthopoxviruses devised mechanisms to prevent activation of this inflammatory protease altogether. Indeed, Myxoma virus and Shope Fibroma virus encode pyrinonly decoy molecules that interfere with inflammasome assembly to inhibit caspase-1 activation (Johnston et al., 2005; Dorfleutner et al., 2007). In this regard, the myxoma virus M013L and Shope
Fibroma virus S013L pyrin-only proteins (POPs) resemble the POPs and caspase recruitment domain (CARD)-only proteins encoded in the human genome (Lamkanfi et al., 2007b; Stehlik and Dorfleutner, 2007). The human CARD-only proteins COP, INCA, ICEBERG, and CASP12 all bind the caspase-1 CARD to prevent activation of caspase- 1 and the subsequent generation of IL-1 $\beta$ (Druilhe et al., 2001; Lee et al., 2001; Lamkanfi et al., 2004a,b; Saleh et al., 2006). In contrast, human cPOP1 and cPOP2, and viral POPs interact with the pyrin domain of the inflammasome adaptor protein ASC and pyrin motifs found in certain NLRs to prevent recruitment and activation of caspase- 1 by inflammasomes (Stehlik and Dorfleutner, 2007). The relevance of vPOPs during infection is provided by the observation that deletion of the gene encoding myxoma virus M013L results in decreased viremia as a result of increased inflammatory responses and attenuated viral replication during myxomatosis (Johnston et al., 2005). Thus, the diverse mechanisms orthopoxviruses evolved to prevent and interfere with caspase- 1 signaling suggest that inflammasomes play a critical role in the host response against these pathogens.

\section{INHIBITION OF INFLAMMASOME SIGNALING BY INFLUENZA VIRUS}

Viral modulation of inflammasome signaling is not limited to the orthopoxviruses described above. Interestingly, Influenza virus uses an unrelated mechanism to prevent caspase- 1 activation and interfere with inflammasome signaling. Human influenza A/PR/8/34 $(\mathrm{H} 1 \mathrm{~N} 1)$ virus was shown to inhibit production of IL-1 $\beta$ and IL-18 through inhibition of caspase-1 maturation in infected macrophages (Stasakova et al., 2005). Mutant viruses lacking the influenza NS1 gene were incapable of preventing caspase- 1 activation and triggered secretion of significantly increased levels of IL-1 $\beta$ and IL-18 from infected host cells. These mutant viruses were attenuated in vitro, but it is unclear whether caspase- 1 activation is solely responsible for this phenotype. Regardless, structure-function studies demonstrated that the amino-terminal RNA-binding/ dimerization domain of NS1 is essential for inhibition of caspase-1 activation and the secretion of mature IL- $1 \beta$ and IL-18, whereas the carboxy-terminal effector domain was not required (Stasakova et al.,2005). Although the molecular mechanism by which influenza NS1 inhibits caspase-1 activation has not been uncovered, NS1 may interfere with a critical step involved in inflammasome assembly. Further study in this direction may unveil interesting new mechanisms by which viruses target inflammasomes.

\section{NEGATIVE REGULATION OF INFLAMMASOME ACTIVATION BY BACTERIAL VIRULENCE FACTORS}

In addition to the viruses described above, several Gram-positive and-Gram-negative bacterial pathogens have been demonstrated to interfere with inflammasome activation. Enteropathogenic Yersinia enterocolitica bacteria employ a set of intriguing mechanisms to prevent caspase- 1 activation and secretion of IL- $1 \beta$ and IL-18 (Schotte et al., 2004). This Gram-negative pathogen makes use of a specialized type III secretion system to inject virulence factors called Yop proteins directly into the host cell cytosol. Among these effector proteins, YopE and YopT were shown to inhibit caspase-1 activation and the subsequent secretion of mature IL-1 $\beta$ (Schotte et al., 2004). These Yop proteins are known to target Rho GTPases, 
which are critical for cytoskeletal reorganization and phagocytosis. YopE accelerates GTP hydrolysis in order to keep Rho GTPase family members in the inactive GDP-bound state. By contrast, YopT is as a cysteine protease that inactivates Rho GTPases by removing the C-terminal prenyl membrane anchor that attaches them to the plasma membrane. Experiments with dominant-negative proteins and chemical inhibitors of the Rho GTPase Racl suggested a critical role for this Rho GTPase in inflammasome assembly and caspase-1 activation (Schotte et al., 2004). In addition to YopE and YopT, the Yersinia pseudotuberculosis effector protein YopK prevents recognition of the bacterial type III secretion system by the Nlrp3 and Nlrc4 inflammasomes in order to promote bacterial survival in host macrophages (Brodsky et al., 2010). Together, these findings suggest that Yersinia spp. may prevent caspase-1 activation by inflammasomes by interfering with Rho GTPases and by masking the type III secretion system. However, the precise molecular chain of events by which Yop effector proteins affect inflammasome activation requires further analysis. L. pneumophila, the causative agent of Legionnaire's disease, uses a different strategy to inhibit caspase-1 activation in human phagocytes. This pathogen downregulates transcription of the inflammasome adaptor ASC to interfere with caspase-1-mediated restriction of bacterial replication in human monocytes (Abdelaziz et al., 2010). P. aeruginosa isolates expressing the virulence factor exoenzyme $U$ (ExoU) represent another example of Gram-negative pathogens interfering with inflammasome activation. Notably, Pseudomonas ExoU phospholipase A2 activity was shown to be required for inhibiting the Nlrc4 inflammasomedriven secretion of IL-1 $\beta$ and IL-18 from infected macrophages (Sutterwala et al., 2007). ExoS is another Pseudomonas effector protein demonstrated to interfere with inflammasome-induced IL-1 $\beta$

\section{REFERENCES}

Abdelaziz, D. H., Gavrilin, M. A., Akhter, A., Caution, K., Kotrange, S., Khweek, A. A., Abdulrahman, B. A., Grandhi, J., Hassan, Z. A., Marsh, C., Wewers, M. D., and Amer, A. O. (2010). ASC controls Legionella pneumophila infection in human monocytes. J. Biol. Chem. doi: M110.197681 [pii] 10.1074/jbc.M110.197681. [Epub ahead of print].

Akhter, A., Gavrilin, M. A., Frantz, L., Washington, S., Ditty, C., Limoli, D., Day, C., Sarkar, A., Newland, C., Butchar, J., Marsh, C. B., Wewers, M. D., Tridandapani, S., Kanneganti, T. D., and Amer, A. O. (2009). Caspase-7 activation by the Nlrc4/Ipaf inflammasome restricts Legionella pneumophila infection. PLoS Pathog. 5, el000361. doi: 10.1371/journal.ppat.1000361

Allen, I. C., TeKippe, E. M., Woodford, R. M., Uronis, J. M., Holl, E. K., Rogers, A. B., Herfarth, H. H., Jobin, C., and Ting, J. P. (2010). The NLRP3 inflammasome functions as a negative regulator of tumorigenesis during colitis-associated cancer. J. Exp. Med. 207, 1045-1056.

Amer, A., Franchi, L., Kanneganti, T. D., Body-Malapel, M., Ozoren, N., Brady,

production. This virulence factor utilized its ADP-ribosyl transferase activity to inhibit caspase- 1 activation (Galle et al., 2008). Also Gram-positive pathogens have evolved mechanisms to interfere with inflammasome function. For instance, Mycobacterium tuberculosis expresses a putative $\mathrm{Zn}^{2+}$ metalloprotease named $\mathrm{Zmp} 1$ that prevents inflammasome activation and IL-1 $\beta$ secretion (Master et al., 2008). Zmpl-mediated inhibition of caspase-1 activation was demonstrated to enhance bacterial survival in infected macrophages and to increase bacterial burdens in the lungs of aerosolinfected mice (Master et al., 2008).

\section{CONCLUSIONS AND PERSPECTIVES}

Caspase- 1 activation by inflammasomes is a critical component of the host response to microbial pathogens. It induces secretion of HMGB1, IL-1 $\beta$, and IL-18 and triggers pyroptosis of infected host cells in order to eliminate the infectious agent. It may thus be beneficial to microbial pathogens to prevent inflammasome assembly, to inhibit caspase-1 activation and activity and to interfere with downstream signaling cascades using decoy receptors. Studies showed that orthopoxviruses, influenza $\mathrm{H} 1 \mathrm{~N} 1$ virus and a variety of bacterial pathogens all evolved unique mechanisms to hijack the inflammasome machinery. Future studies will undoubtedly shed light on new and intriguing mechanisms by which bacterial and viral pathogens aim to silence the inflammasome.

\section{ACKNOWLEDGMENTS}

This work was supported by the European Union Framework Program 7 Marie-Curie grant 256432 and by fellowships from the Fund for Scientific Research - Flanders to Mohamed Lamkanfi and Lieselotte Vande Walle.

interleukin-1 family. Annu. Rev. Immunol. 27, 519-550.

Dobbelstein, M., and Shenk, T. (1996). Protection against apoptosis by the vaccinia virus SPI-2 (B13R) gene product. J. Virol. 70, 6479-6485.

Dorfleutner, A., Talbott, S. J., Bryan, N. B., Funya, K. N., Rellick, S. L., Reed, J. C., Shi, X., Rojanasakul, Y., Flynn, D. C., and Stehlik, C. (2007). A shope fibroma virus PYRIN-only protein modulates the host immune response. Virus Genes 35, 685-694.

Druilhe, A., Srinivasula, S. M., Razmara, M., Ahmad, M., and Alnemri, E. S. (2001). Regulation of IL-1beta generation by Pseudo-ICE and ICEBERG, two dominant negative caspase recruitment domain proteins. Cell Death Differ. 8, 649-657.

Dupaul-Chicoine, J., Yeretssian, G., Doiron, K., Bergstrom, K. S., McIntire, C. R., LeBlanc, P. M., Meunier, C., Turbide, C., Gros, P., Beauchemin, N., Vallance, B. A., and Saleh, M. (2010). Control of intestinal homeostasis, colitis, and colitis-associated colorectal cancer by the inflammatory caspases. Immunity 32, 367-378.

Fernandes-Alnemri, T., Yu, J. W., Juliana, C., Solorzano, L., Kang, S., Wu, J.,
Datta, P., McCormick, M., Huang, L., McDermott, E., Eisenlohr, L., Landel, C. P., and Alnemri, E. S. (2010). The AIM2 inflammasome is critical for innate immunity to Francisella tularensis. Nat. Immunol. 11, 385-393.

Franchi, L., Amer, A., Body-Malapel, M., Kanneganti, T.D., Ozoren, N., Jagirdar, R., Inohara, N., Vandenabeele, P., Bertin, J., Coyle, A., Grant, E. P., and Nunez, G. (2006). Cytosolic flagellin requires Ipaf for activation of caspase-1 and interleukin lbeta in Salmonella-infected macrophages. Nat. Immunol. 7, 576-582.

Franchi, L., Stoolman, J., Kanneganti, T. D., Verma, A., Ramphal, R., and Nunez, G. (2007). Critical role for Ipaf in Pseudomonas aeruginosa-induced caspase- 1 activation. Eur. J. Immunol. 37, 3030-3039.

Galle, M., Schotte, P., Haegman, M., Wullaert, A., Yang, H. J., Jin, S., and Beyaert, R. (2008). The Pseudomonas aeruginosa Type III secretion system plays a dual role in the regulation of caspase-1 mediated IL-1beta maturation. J. Cell. Mol. Med. 12, 1767-1776.

Ghayur, T., Banerjee, S., Hugunin, M., Butler, D., Herzog, L., Carter, A., 
Quintal, L., Sekut, L., Talanian, R., Paskind, M., Wong, W., Kamen, R., Tracey, D., and Allen, H. (1997). Caspase-1 processes IFN-gammainducing factor and regulates LPSinduced IFN-gamma production. Nature 386, 619-623.

Gu, Y., Kuida, K., Tsutsui, H., Ku, G. Hsiao, K., Fleming, M. A., Hayashi, N., Higashino, K., Okamura, H., Nakanishi, K., Kurimoto,M., Tanimoto, T., Flavell, R. A., Sato, V., Harding, M. W., Livingston, D. J., and Su, M. S. (1997). Activation of interferon-gamma inducing factor mediated by interleukin-1beta converting enzyme. Science 275, 206-209.

Johnston, J. B., Barrett, J. W., Nazarian, S. H., Goodwin, M., Ricciuto, D., Wang, G., and McFadden, G. (2005). A poxvirus-encoded pyrin domain protein interacts with ASC-1 to inhibit host inflammatory and apoptotic responses to infection. Immunity 23, 587-598.

Jones, J. W., Kayagaki, N., Broz, P., Henry, T., Newton, K., O'Rourke, K., Chan, S., Dong, J., Qu, Y., Roose-Girma, M., Dixit, V. M., and Monack, D. M. (2010). Absent in melanoma 2 is required for innate immune recognition of Francisella tularensis. Proc. Natl. Acad. Sci. U.S.A. 107, 9771-9776.

Kanneganti, T. D., Ozoren, N., BodyMalapel, M., Amer, A., Park, J. H., Franchi, L., Whitfield, J., Barchet, W., Colonna, M., Vandenabeele, P., Bertin, J., Coyle, A., Grant, E. P., Akira, S., and Nunez, G. (2006a). Bacterial RNA and small antiviral compounds activate caspase-1 through cryopyrin/Nalp3. Nature 440, 233-236.

Kanneganti, T.D., Body-Malapel,M.,Amer, A., Park, J. H., Whitfield, J., Franchi, L., Taraporewala, Z.F., Miller, D., Patton, J. T., Inohara, N., and Nunez, G. (2006b). Critical role for cryopyrin/Nalp3 in activation of caspase-1 in response to viral infection and double-stranded RNA. J. Biol. Chem. 281, 36560-36568.

Kawai, T., and Akira, S. (2006). TLR signaling. Cell Death Differ. 13, 816-825.

Kettle, S., Alcami, A., Khanna, A., Ehret, R., Jassoy, C., and Smith, G. L. (1997). Vaccinia virus serpin B13R (SPI-2) inhibits interleukin-1beta-converting enzyme and protects virus-infected cells from TNF- and Fas-mediated apoptosis, but does not prevent IL-1beta-induced fever. J. Gen. Virol. 78(Pt 3), 677-685.

Kettle, S., Blake, N. W., Law, K. M., and Smith, G. L. (1995). Vaccinia virus serpins B13R (SPI-2) and B22R (SPI-1) encode $\mathrm{M}(\mathrm{r}) 38.5$ and $40 \mathrm{~K}$, intracellular polypeptides that do not affect virus virulence in a murine intranasal model. Virology 206, 136-147.

Komiyama, T., Ray, C. A., Pickup, D. J., Howard, A. D., Thornberry, N. A., Peterson, E. P., and Salvesen, G. (1994)
Inhibition of interleukin-1 beta converting enzyme by the cowpox virus serpin CrmAn A., example of crossclass inhibition. J. Biol. Chem. 269, 19331-19337.

Kuida, K., Lippke, J. A., Ku, G., Harding M. W., Livingston, D. J., Su, M. S., and Flavell, R. A. (1995). Altered cytokine export and apoptosis in mice deficient in interleukin-1 beta converting enzyme. Science 267, 2000-2003.

Lamkanfi, M., Amer, A., Kanneganti, T. D., Munoz-Planillo, R., Chen, G., Vandenabeele, P., Fortier, A., Gros, P., and Nunez, G. (2007a). The Nod-like receptor family member Naip $5 /$ Bircle restricts Legionellapneumophila growth independently of caspase-1 activation. J. Immunol. 178, 8022-8027.

Lamkanfi, M., Festjens, N., Declercq, W., Vanden, T., Berghe, and Vandenabeele, P. (2007b). Caspases in cell survival, proliferation and differentiation. Cell Death Differ. 14, 44-55.

Lamkanfi, M., Declercq, W., Kalai, M., Saelens, X., and Vandenabeele, P. (2002). Alice in caspase land. A phylogenetic analysis of caspases from worm to man. Cell Death Differ. 9, 358-361.

Lamkanfi, M., Declercq, W., Vanden, T., Berghe, and Vandenabeele, P. (2006). Caspases leave the beaten track: caspase-mediated activation of NF-kappaB. J. Cell Biol. 173, 165-171.

Lamkanfi, M., Denecker, G., Kalai, M., D'Hondt, K., Meeus, A., Declercq, W., Saelens, X., and Vandenabeele, P. (2004a). INCA, a novel human caspase recruitment domain protein that inhibits interleukin-1beta generation. J. Biol. Chem. 279, 51729-51738.

Lamkanfi,M.,Kalai,M., andVandenabeele, P. (2004b). Caspase-12: an overview. Cell Death Differ. 11, 365-368.

Lamkanfi, M., and Dixit, V. M. (2009). The inflammasomes. PLoS Pathog. 5, e1000510. doi: 10.1371/journal. ppat. 1000510

Lamkanfi, M., and Dixit, V. M. (2010). Manipulation of host cell death pathways during microbial infections. Cell Host Microbe 8, 44-54.

Lamkanfi, M., and Kanneganti, T. D. (2010). Nlrp3: an immune sensor of cellular stress and infection. Int. J. Biochem. Cell Biol. 42, 792-795.

Lamkanfi, M., Kanneganti, T. D., Van Damme, P., Vanden Berghe, T., Vanoverberghe, I., Vandekerckhove, J., Vandenabeele,P.,Gevaert,K., and Nunez, G. (2008). Targeted peptidecentric proteomics reveals caspase- 7 as a substrate of the caspase- 1 inflammasomes. Mol. Cell Proteomics 7, 2350-2363.

Lamkanfi, M., Sarkar, A., Vande Walle, L. Vitari, A. C., Amer, A. O., Wewers, M. D., Tracey, K. J., Kanneganti, T. D., and
Dixit, V. M. (2010). Inflammasomedependent release of the alarmin HMGB1 in endotoxemia. J. Immunol. 185, 4385-4392.

Larsen, C. M., Faulenbach, M., Vaag, A. Volund, A., Ehses, J. A., Seifert, B. Mandrup-Poulsen, T., and Donath M. Y. (2007). Interleukin-1-receptor antagonist in type 2 diabetes mellitus. N. Engl. J. Med. 356, 1517-1526.

Lee, S. H., Stehlik, C., and Reed, J. C. (2001). Cop, a caspase recruitment domain-containing protein and inhibitor of caspase-1 activation processing. J. Biol. Chem. 276, 34495-34500.

Li, P., Allen, H., Banerjee, S., Franklin, S. Herzog, L., Johnston, C., McDowell, J., Paskind, M., Rodman, L., Salfeld, J., Towne, E., Tracey, D., Wardwell, S., Wei, F., Wong, W., Kamen, R., and Seshadri, T. (1995). Mice deficient in IL-1 beta-converting enzyme are defective in production of mature IL-1 beta and resistant to endotoxic shock. Cell 80, 401-411.

Macen, J. L., Garner, R. S., Musy, P. Y., Brooks, M. A., Turner, P. C., Moyer, R. W., McFadden, G., and Bleackley, R. C. (1996). Differential inhibition of the Fas- and granule-mediated cytolysis pathways by the orthopoxvirus cytokine response modifier $\mathrm{A}$ / SPI-2 and SPI-1 protein. Proc. Natl. Acad. Sci. U.S.A. 93, 9108-9113.

MacNeill, A. L., Moldawer, L. L., and Moyer, R. W. (2009). The role of the cowpox virus crmA gene during intratracheal and intradermal infection of C57BL/6 mice. Virology 384 151-160.

Mariathasan, S., Newton, K., Monack, D. M., Vucic, D., French, D. M., Lee W. P., Roose-Girma, M., Erickson, S. and Dixit, V. M. (2004). Differential activation of the inflammasome by caspase- 1 adaptors ASC and Ipaf. Nature 430, 213-218.

Mariathasan, S., Weiss, D. S., Newton, K., McBride, J., O’Rourke, K., RooseGirma, M., Lee, W. P., Weinrauch Y., Monack, D. M., and Dixit, V. M. (2006). Cryopyrin activates the inflammasome in response to toxins and ATP. Nature 440, 228-232.

Martinon, F., Petrilli, V., Mayor, A., Tardivel, A., and Tschopp, J. (2006) Gout-associated uric acid crystals activate the NALP3 inflammasome. Nature 440, 237-241.

Master, S. S., Rampini, S. K., Davis, A S., Keller, C., Ehlers, S., Springer, B. Timmins, G.S., Sander, P., and Deretic, V. (2008). Mycobacterium tuberculosis prevents inflammasome activation. Cell Host Microbe 3, 224-32.

McNeela, E. A., Burke, A., Neill, D. R., Baxter, C., Fernandes, V. E., Ferreira, D., Smeaton, S., El-Rachkidy, R., McLoughlin, R. M., Mori, A., Moran,
B., Fitzgerald, K. A., Tschopp, J., Petrilli, V., Andrew, P. W., Kadioglu, A., and Lavelle, E.C. (2010). Pneumolysin activates the NLRP3 inflammasome and promotes proinflammatory cytokines independently of TLR4. PLoS Pathog. 6, e1001191. doi: 10.1371/journal. ppat.1001191

Messud-Petit, F., Gelfi, J., Delverdier, M., Amardeilh, M. F., Py, R., Sutter, G., and Bertagnoli, S. (1998). Serp2, an inhibitor of the interleukin-1betaconverting enzyme, is critical in the pathobiology of myxoma virus. $J$. Virol. 72, 7830-7839.

Miao, E.A.,Alpuche-Aranda, C.M., Dors, M., Clark, A. E., Bader, M. W., Miller, S. I., and Aderem, A. (2006). Cytoplasmic flagellin activates caspase- 1 and secretion of interleukin lbeta via Ipaf. Nat. Immunol. 7, 569-575.

Miao, E. A., Ernst, R. K., Dors, M., Mao, D. P., and Aderem, A. (2008). Pseudomonas aeruginosa activates caspase 1 through Ipaf. Proc. Natl. Acad. Sci. U.S.A. 105, 2562-2567.

Miao, E.A., Leaf, I. A., Treuting, P.M., Mao, D. P., Dors, M., Sarkar, A., Warren, S.E., Wewers, M.D., and Aderem, A. (2010). Caspase-1-induced pyroptosis is an innate immune effector mechanism against intracellular bacteria. Nat. Immunol. 11, 1136-1142.

Palumbo, G. J., Buller, R. M., and Glasgow, W. C. (1994). Multigenic evasion of inflammation by poxviruses. J. Virol. $68,1737-1749$

Rathinam, V.A., Jiang, Z., Waggoner, S. N. Sharma, S., Cole, L. E., Waggoner, L., Vanaja, S. K., Monks, B. G., Ganesan, S., Latz, E., Hornung, V., Vogel, S. N., Szomolanyi-Tsuda E., and Fitzgerald, K. A. (2010). The AIM2 inflammasome is essential for host defense against cytosolic bacteria and DNA viruses. Nat. Immunol. 11, 395-402.

Ray, C. A., Black, R. A., Kronheim, S. R., Greenstreet, T. A., Sleath, P. R., Salvesen, G. S., and Pickup, D.J. (1992). Viral inhibition of inflammation: cowpox virus encodes an inhibitor of the interleukin- 1 beta converting enzyme. Cell 69, 597-604.

Saleh, M., Mathison, J.C., Wolinski, M. K. Bensinger, S. J., Fitzgerald, P., Droin, N., Ulevitch, R. J., Green, D. R., and Nicholson, D. W. (2006). Enhanced bacterial clearance and sepsis resistance in caspase-12-deficient mice. Nature 440, 1064-1068.

Sauer, J. D., Witte, C. E., Zemansky, J. Hanson, B., Lauer, P., and Portnoy, D. A. (2010). Listeria monocytogenes triggers AIM2-mediated pyroptosis upon infrequent bacteriolysis in the macrophage cytosol. Cell Host Microbe 7, 412-419.

Schotte, P., Denecker, G., Van Den Broeke, A., Vandenabeele, P., Cornelis, G. R., 
and Beyaert, R. (2004). Targeting Rac1 by the Yersinia effector protein YopE inhibits caspase-1-mediated maturation and release of interleukin-1beta. J. Biol. Chem. 279, 25134-25142.

Shao, W., Yeretssian, G., Doiron, K., Hussain, S. N., and Saleh, M. (2007). The caspase-1 digestome identifies the glycolysis pathway as a target during infection and septic shock. J. Biol. Chem. 282, 36321-36329.

Smith, V. P., Bryant, N. A., and Alcami, A. (2000). Ectromelia, vaccinia and cowpox viruses encode secreted interleukin-18-binding proteins. J. Gen. Virol. 81(Pt 5), 1223-1230.

Sprecher, C. A., Morgenstern, K. A., Mathewes, S., Dahlen, J.R., Schrader, S. K., Foster, D. C., and Kisiel, W. (1995). Molecular cloning, expression, and partial characterization of two novel members of the ovalbumin family of serine proteinase inhibitors. J. Biol. Chem. 270, 29854-29861.

Stasakova, J., Ferko, B., Kittel, C., Sereinig, S., Romanova, J., Katinger, H., and Egorov, A. (2005). Influenza A mutant viruses with altered NS1 protein function provoke caspase- 1 activation in primary human macrophages, resulting in fast apoptosis and release of high levels of interleukins 1beta and 18. J. Gen. Virol. 86(Pt 1), 185-195.

Stehlik, C., and Dorfleutner, A. (2007). COPs and POPs: modulators of inflammasome activity. J. Immunol. 179, 7993-7998.

Sun, J., Ooms, L., Bird, C. H., Sutton, V. R. Trapani, J. A., and Bird, P. I. (1997). A new family of 10 murine ovalbumin serpins includes two homologs of proteinase inhibitor 8 and two homologs of the granzyme B inhibitor (proteinase inhibitor 9). J. Biol. Chem. 272, 15434-15441.

Sutterwala, F. S., Mijares, L.A., Li, L., Ogura, Y., Kazmierczak, B. I., and Flavell, R. A. (2007). Immune recognition of Pseudomonas aeruginosa mediated by the IPAF/NLRC4 inflammasome. J. Exp. Med. 204, 3235-3245.

Sutterwala, F. S., Ogura, Y., Szczepanik, M., Lara-Tejero, M., Lichtenberger, G. S., Grant, E. P., Bertin, J., Coyle, A. J., Galan, J.E., Askenase, P.W., and Flavell, R. A. (2006). Critical role for NALP3/ CIAS1/cryopyrin in innate and adaptive immunity through its regulation of caspase-1. Immunity 24, 317-327.

Suzuki, T., Franchi, L., Toma, C., Ashida, H., Ogawa, M., Yoshikawa, Y., Mimuro, H., Inohara, N., Sasakawa, C., and Nunez, G. (2007). Differential regulation of caspase- 1 activation, pyroptosis, and autophagy via Ipaf and ASC in Shigella-infected macrophages. PLoS Pathog. 3, el11. doi: 10.1371/journal. ppat.0030111

Thompson, J. P., Turner, P. C., Ali, A. N., Crenshaw, B. C., and Moyer, R. W.
(1993). The effects of serpin gene mutations on the distinctive pathobiology of cowpox and rabbitpox virus following intranasal inoculation of Balb/c mice. Virology 197, 328-338.

Turner, S. J., Silke, J., Kenshole, B., and Ruby, J. (2000). Characterization of the ectromelia virus serpin, SPI-2. J. Gen. Virol. 81(Pt 10), 2425-2430.

Villani,A.C., Lemire, M., Fortin, G., Louis, E., Silverberg, M. S., Collette, C., Baba, N., Libioulle, C., Belaiche, J., Bitton, A., Gaudet, D., Cohen, A., Langelier D., Fortin, P. R., Wither, J. E., Sarfati M., Rutgeerts, P., Rioux, J. D., Vermeire, S., Hudson, T. J., and Franchimont, D. (2009). Common variants in the NLRP3 region contribute to Crohn's disease susceptibility. Nat. Genet. 41, 71-76.

Young, J. L., Sukhova, G. K., Foster, D., Kisiel, W., Libby, P., and Schonbeck, U. (2000). The serpin proteinase inhibitor 9 is an endogenous inhibitor of interleukin lbeta-converting enzyme (caspase-1) activity in human vascular smooth muscle cells. J. Exp. Med. 191, 1535-1544.

Zaki, M. H., Boyd, K. L., Vogel, P., Kastan, M. B., Lamkanfi, M., and Kanneganti, T. D. (2010a). The NLRP3 inflammasome protects against loss of epithelial integrity and mortality during experimental colitis. Immunity 32 , 379-391.
Zaki, M. H., Vogel, P., Body-Malapel, M. Lamkanfi, M., and Kanneganti, T. D. (2010b). IL-18 production downstream of the Nlrp3 inflammasome confers protection against colorectal tumor formation. J. Immunol. 185, 4912-4920

Conflict of Interest Statement: The authors declare that the research was conducted in the absence of any commercial or financial relationships that could be construed as a potential conflict of interest.

Received: 14 November 2010; paper pending published: 05 December 2010; accepted: 07 January 2011; published online: 25 January 2011.

Citation: Vande Walle L and Lamkanf $M$ (2011) Inflammasomes: caspase-1activating platforms with critical roles in host defense. Front. Microbio. 2:3. doi: 10.3389/fmicb.2011.00003

This article was submitted to Frontiers in Cellular and Infection Microbiology, a specialty of Frontiers in Microbiology. Copyright (c) 2011 Vande Walle and Lamkanfi. This is an open-access article subject to an exclusive license agreement between the authors and Frontiers Media $S A$, which permits unrestricted use, distribution, and reproduction in any medium, provided the original authors and source are credited. 